\title{
Indian Perspectives on Supply Chain Management: A Special Issue
}

\author{
Bimaraya Metri, Special Issue Editor \\ International Management Institute, New Delhi, India \\ E-mail: metri@imi.edu \\ I Nyoman Pujawan, Special Issue Editor \\ Sepuluh Nopember Institute of Technology, Surabaya, Indonesia \\ E-mail: pujawan@ie.its.ac.id
}

The $5^{\text {th }}$ International Conference on Operations and Supply Chain Management (OSCM) was held in New Delhi, India in conjuction with the $7^{\text {th }}$ Indian Subcontinent Decision Sciences Institute (ISDSI) in December 2013. The conference successfully attracted over 150 papers. In this special issue we selected six papers, all are addressing supply chain management problems in the Indian context, covering various aspects of supply chain management such as supply chain flexibility (Singh \& Acharya, 2014), knowledge management (Baig et al., 2014), customer satisfaction or service quality (Itumalla, et al, 2014), and supplier selection (Dilgawar et al, 2014). Different industry sectors are also addressed, including the printing industry (Acharyulu, 2014); Fast moving consumer goods (Singh \& Acharya, 2014), healthcare (Itumalla, et al., 2014), and online retailing (Kandulapati and Bellamkonda, 2014).

India is obviously one of the biggest economy in the world nowadays and supply chain has been the major contributor for the running of the Indian economy. It is expected that the practice of supply chain management varies from one country to the other, and this special issue brings to you a perspective from Indian context that could enrich your global view of the supply chain management.

This special issue would not be possible without contribution of many people. We would like to thank all the contributors of the six papers in this special issue. We also owe our thanks to all reviewers who have given comments for improving the manuscripts. Finally we hope that this special issue brings useful reading materials for the interested readers.

\section{REFERENCES}

Acharyulu, G.V.R.K. (2014). Supply chain management practices in printing industry. Operations and Supply Chain Management 7 (2), pp. 39 - 45.

Digalwar, A. K., Borade, A. and Metri, B. (2014). A Fuzzy AHP Approach for supplier selection. Operations and Supply Chain Management 7 (2), pp. 46 - 53.

Itumalla, R., Acharyulu, G.V.R.K., Shekhar, B. R. (2014). Development of HospitalQual: A service quality scale for measuring In-patient services in hospital. Operations and Supply Chain Management 7 (2), pp. 54 - 63.

Singh, R. K. and Acharya, P. (2014). An AHP model approach to supply chain flexibility: A case study of Indian FMCG firm. Operations and Supply Chain Management 7 (2), pp. 64 - 69.

Kandulapati, S., and Bellamkonda, R. S. (2014). Examining the structural relationships of service recovery, customer satisfaction and image in online retailing. Operations and Supply Chain Management 7 (2), pp. 70 - 78.

Baig, V. A., Akhter, J., Shahid, M., and Rehman, A. (2014). Knowledge management and supply chain - A study in Indian perspective. Operations and Supply Chain Management 7 (2), pp. $79-88$. 